\title{
Comparative study of two serological tests for detection of anti- Theileria equi antibodies in horses
}

\section{Estudo comparativo de dois testes sorológicos para detecção de anticorpos anti-Theileria equi em equinos}

\author{
Thállitha Samih Wischral Jayme Vieira ${ }^{1}$; Jessica Damiana Marinho Valente²; \\ Nayara Bezerra Silva ${ }^{3}$; Patrícia Mara Lopes Sicupira'; Ivan Roque Barros-Filho ${ }^{4}$; \\ Alexander Welker Biondo ${ }^{4}$; Rafael Felipe da Costa Vieira ${ }^{4}$; Odilon Vidotto ${ }^{5 *}$
}

\begin{abstract}
Theileria equi is the causative agent of worldwide piroplasmosis, an important tick-borne disease of equids associated to a lifetime carrier state of infected horses. Since rapid, accessible and reliable tests have been posted as a challenge for clinicians, the aim of the present study was to verify the agreement between an in-house immunofluorescence antibody assay (IFA) and a commercial competitive inhibition enzyme-linked immunosorbent assay (cELISA) in a population of 198 carthorses from Southern Brazil. The horse seroreactivity for T. equi revealed 152/198 (76.8\%) positive samples by IFA and 155/198 (78.3\%) by cELISA. Using cELISA as gold standard, IFA has shown a sensitivity of $91.6 \%(95 \%$ $\mathrm{CI}=86.18-95.03 \%)$ and specificity of $76.7 \%(95 \% \mathrm{CI}=62.26-86.85 \%)$, with a substantial degree of agreement $(\mathrm{k}=0.8445)$. In conclusion, the in-house IFA may be used as a screening test for diagnosis of equine piroplasmosis.
\end{abstract}

Key words: Piroplasmosis, equids, seroepidemiology, theileriosis

\section{Resumo}

Theileria equi é o agente causador da piroplasmose no mundo, é uma importante doença transmitida por carrapatos nos equídeos em todo o mundo, e está associada ao estado de portador nos equinos infectados. Uma vez que testes rápidos, acessíveis e confiáveis são considerados um desafio para os clínicos, o objetivo do presente estudo foi avaliar a concordância entre os testes de imunofluorescência indireta (RIFI) e um ensaio imunoenzimático por competição comercial (cELISA) em uma população de 198 equinos de tração na região Sul do Brasil. A sororreatividade dos cavalos para T. equi mostrou 152/198 (76.8\%) amostras positivas para RIFI e 155/198 (78.3\%) amostras positivas para cELISA. Utilizando o cELISA como padrão ouro, a RIFI demonstrou sensibilidade de $91.6 \%(95 \% \mathrm{CI}=86.18-95.03 \%)$ e especificidade de $76.7 \%(95 \% \mathrm{CI}=62.26-86.85 \%)$, com uma concordância de grau substancial $(\mathrm{k}$ $=0.8445)$. Em conclusão, a RIFI pode ser utilizada como um teste de triagem para o diagnóstico de piroplasmose equina.

Palavras-chave: Piroplasmose, equídeos, soroepidemiologia, teileriose

\footnotetext{
${ }^{1}$ Discentes do Programa de Pós-Graduação em Ciência Animal, Universidade Estadual de Londrina, UEL, Londrina, PR, Brasil. E-mail: vieiratswj@gmail.com; patricialopes_sicupira@hotmail.com

${ }^{2}$ Residente do programa de residência multiprofissional, Universidade Federal do Paraná, UFPR, Curitiba, PR, Brasil. E-mail: jessica.d.02@hotmail.com

3 Médica Veterinária, Curitiba, PR, Brasil. E-mail: nsilva17@hotmail.com

${ }^{4}$ Profs., Dept ${ }^{\mathrm{o}}$ de Medicina Veterinária, UFPR, Curitiba, PR, Brasil. E-mail: ivanbarf@ufpr.br; abiondo@ufpr.br; rvieira@ufpr.br

${ }^{5}$ Prof. Dr., Dept ${ }^{\circ}$ de Medicina Veterinária Preventiva, UEL, Londrina, PR, Brasil. E-mail: vidotto@uel.br

* Author for correspondence
} 
Theileria equi is the causative agent of Equine Piroplasmosis (EP), an important worldwide tickborne disease which causes a lifetime carrier state in infected horses (SCHNITTGER et al., 2012). Diagnosis of EP has historically relied on immunofluorescence antibody assay (IFA) and reportedly considered very effective in detecting long-term infected animals and those submitted to antiparasitic treatment (OIE, 2014), despite several drawbacks of IFA including subjective operatordependent interpretation of results (KATENDE et al., 1998). Due to such limitations, associated to negative economic impact of EP on the horse industry, the World Organization for Animal Health has replaced the IFA by a commercial competitive inhibition enzyme-linked immunosorbent assay (cELISA) as standard serological tool for international trade purposes, particularly on detection of carriers (OIE, 2014).

Although cELISA has been successfully used to evaluate Brazilian carthorses (VIEIRA et al., 2013), the routinely diagnostic use of this test in Brazil has been considered of limited assess, mainly due to high costs and importation delays. Moreover, to the authors' knowledge, no study on comparative performance of IFA using a Brazilian T. equi strain versus the officially recommended cELISA in detecting anti- $T$. equi antibodies has been reported to date. Accordingly, the aim of the present study was to verify the agreement between IFA and cELISA methods in a population of 198 carthorses from Southern Brazil.

Horse serum samples $(\mathrm{n}=198)$ previously surveyed for tick-borne pathogens (VIEIRA et al., 2013, 2015) were used in this study. All samples were kept at $-80{ }^{\circ} \mathrm{C}$ until serological analysis were performed. Theileria equi strain was obtained and isolated from a horse at the Veterinary Teaching Hospital, at Universidade Estadual de Londrina, Paraná State, southern Brazil. The isolate was maintained cryopreserved in liquid nitrogen for blood stability containing 10\% dimethyl sulfoxide. The T. equi soluble antigen for the indirect immnufluorescent antibody assay (IFA) was prepared by the inoculation of the strain intravenously in a splenectomized foal free from hemoparasites, as previously described (MADRUGA et al., 1986).

Promptly, the blood with $10 \%$ T. equi parasitemia was collected and washed with phosphate buffered saline (PBS, $\mathrm{pH}$ 7.2) by centrifugation at $1000 \mathrm{~g}$ for $15 \mathrm{~min}$. After each centrifugation, the buffy coat was removed. Then, thin blood smears were prepared and stored at $-80{ }^{\circ} \mathrm{C}$. At the moment of analyses, smears were dried for $10 \mathrm{~min}$ at $37^{\circ} \mathrm{C}$ and circles were drawn with finger nail polish.

Anti-T. equi antibodies in horse serum samples were evaluated by an in-house IFA and a commercial cELISA test kit (Babesia equi antibody test kit, VMRD $^{\circledR}$ Inc., Pullman, WA, USA) as previously published (VIEIRA et al., 2013). For IFA, an amount of $10 \mu \mathrm{L}$ of serum, diluted 1:80 in PBS, was added to each circle on the slide and incubated at $37{ }^{\circ} \mathrm{C}$ for $30 \mathrm{~min}$, washed three times for $5 \mathrm{~min}$ in $\mathrm{PBS}, \mathrm{pH} 7.2$, additionally washed by distilled water, then dried at room temperature. Twenty microliters of fluorescein isothiocyanate-conjugated rabbit anti-horse IgG (Sigma-Aldrich, St. Louis, MO) at 1:160 dilution in PBS with $1 \%$ of bovine serum albumin and $1 \%$ Evans blue were applied onto the slide. Slides were then incubated at $37{ }^{\circ} \mathrm{C}$ for 30 min, washed three times for $5 \mathrm{~min}$, additionally washed by distilled water, allowed to air dry and subsequently examined using a microscope with a fluorescent light source. Samples were considered positive when reacting with dilution $\geq 1: 80$ (BALDANI et al., 2010). Titers were determined to the largest dilution in which fluorescence was visualized around the parasite (endpoint titers).

Agreement (Kappa) between IFA and cELISA tests and the evaluation of IFA sensitivity, specificity, positive and negative predict values were calculated using OpenEpi software (DEAN et al., 2004), with cELISA as gold standard. Kappa value $(\kappa)$ was interpreted as follows: $\leq 0$ poor, 0.01 0.2 slight, 0.21-0.4 fair, 0.41-0.6 moderate, 0.61-0.8 
substantial, and 0.81-1 almost perfect agreement (VIERA; GARRETT, 2005).

A total of $152 / 198(76.8 \% ; 95 \% \mathrm{CI}=70.4-82.1 \%)$ horses were seroreactive for $T$. equi by IFA, with antibody titers ranging from 80 to 2560 . Seroreactive to $T$. equi by cELISA was found in $155 / 198$ (78.3\%; 95\% CI: 71.9-83.8\%) horses. Using cELISA as gold standard, the resulting sensitivity and specificity for IFA were $91.6 \%(95 \% \mathrm{CI}=86.18-95.03 \%)$ and $76.7 \%$ (95\% CI $=62.26-86.85 \%)$, and positive and negative predictive values were $93.4 \%(95 \%$ $\mathrm{CI}=88.31-96.39 \%)$ and $71.7 \%(95 \% \mathrm{CI}=57.45$ $82.68 \%$ ), respectively, showing a substantial degree of agreement ( $\kappa=0.67 ; 95 \% \mathrm{CI}=0.53-0.80)$.

In the present study, a substantial degree of agreement was found between IFA and cELISA. These two methods were previously evaluated resulting in an almost perfect degree of agreement between cELISA and IFA (SHKAP et al., 1998; FARKAs et al., 2013). Differences found between studies may be attributed to the T. equi antigen used on IFA, since the present study used a Brazilian $T$. equi strain while others have used a commercial IFA. In Brazil, previous studies have found an almost perfect agreement between IFA and an inhouse ELISA using a Brazilian T. equi strain as antigen (GOLYNSKI et al., 2008; SANTOS et al., 2009), showing that both tests are suitable for serodiagnosis and epidemiological studies.

Tests using specific antigens, such as the cELISA herein used, are more specific due to the decreased possibilities of cross-reactions with nonspecific antibodies, while tests using crude antigens have been found to be more sensitive (HARRUS et al., 2002). The present study is in agreement with the study previously mentioned, since the IFA sensitivity was $91.6 \%$ and specificity was $76.7 \%$. Thus, due to the limitations for cELISA use, authors suggest that IFA may be useful as screening test in Brazil.

In conclusion, this in-house IFA may be helpfully used for the detection of anti-T. equi antibodies as a screening method for the diagnosis of equine piroplasmosis.

\section{References}

BALDANI, C. D.; NAKAGHI, A. C. H.; MACHADO, R. Z. Occurrence of Theileria equi in horses raised in the Jaboticabal microregion, São Paulo State, Brazil. Brazilian Journal of Veterinary Parasitology, Jaboticabal, v. 19, n. 4, p. 228-32, 2010.

DEAN, A. G.; SULLIVAN, K. M.; SOE, M. M. OpenEpi: open source epidemiologic statistics for public health. [S.l. : s.n.], 2004. Available at: <http://www.openepi. com>. Accessed at: 06 aug. 2015.

FARKAS, R.; TÁNCZOS, B.; GYURKOVSZKY, M.; FÖLDVÁRI, G.; SOLYMOSI, N.; EDELHOFER, R.; HORNOK, S. Serological and molecular detection of Theileria equi infection in horses in Hungary. Veterinary Parasitology, Amsterdam, v. 192, n. 1-3, p. 143-8, 2013.

GOLYNSKI, A. A.; FERNANDES, K. R.; BALDANI, C. D.; GOLYNSKI, A. L.; MADEIRO, A. S.; MACHADO, R. Z.; BOTTEON, P. de T. L.; MASSARD, C. L. Estudo soroepidemiológico da Babesia equi em equinos do estado do Rio Grande do Sul, Brasil, determinado pelos testes de imunofluorescência indireta e Elisa. Revista Brasileira de Parasitologia Veterinária, São Carlos, v. 17, n. 1, p. 317-321, 2008.

HARRUS, S.; ALLEMAN, A. R.; BARK, H.; MAHAN, S. M.; WANER, T. Comparison of three enzyme-linked immunosorbant assays with the indirect immunofluorescent antibody test for the diagnosis of canine infection with Ehrlichia canis. Veterinary Microbiology, Barcelona, v. 86, n. 4, p. 361-8, 2002.

KATENDE, J.; MORZARIA, S.; TOYE, P.; SKILTON, R.; NENE, V.; NKONGE, C.; MUSOKE, A. An enzyme-linked immunosorbent assay for detection of Theileria parva antibodies in cattle using a recombinant polymorphic immunodominant molecule. Parasitology Research, Berlin, v. 84, n. 5, p. 408-16, 1998.

MADRUGA, C. R.; KESSLER, R. H.; SACCO, A. M. S.; JESUS, E. F. de; MIGUITA, C. T. Produção de antígenos $e$ análise preliminar do teste de Imunofluorescência Indireta para diagnóstico de anticorpos contra Anaplasma marginale. Campo Grande: EMBRAPACNPGC, 1986. 4 p. (Circular técnico, n. 31).

SANTOS, T. M. dos; FERRAZ, P. N.; ALMEIDA, F. Q. de; MASSARD, C. L.; BALDANI, C. D.; BOTTEON, P. de T. L.; SANTOS, H. A.; MACHADO, R. Z.; ANDRADE, C. de M. Comparative studies of three 
methods for detection Theileria equi antibody in endemic areas horses from Rio de Janeiro state. Brazilian Journal of Veterinary Research and Animal Science, São Paulo, v. 46, n. 6, p. 484-490, 2009.

SCHNITTGER, L.; RODRIGUEZ, A. E.; FLORINCHRISTENSEN, M.; MORRISON, D. A. Babesia: a world emerging. Infection, Genetics and Evolution, v. 12, n. 8, p. 1788-809, 2012.

SHKAP, V.; COHEN, I.; LEIBOVITZ. B.; SAVITSKY; PIPANO, E.; AVNI, G.; SHOFER, S.; GIGER, U.; KAPPMEYER, L.; KNOWLES, D. Seroprevalence of Babesia equi among horses in Israel using competitive inhibition ELISA and IFA assays. Veterinary Parasitology, Amsterdam, v. 76, n. 4, p. 251-259, 1998.

VIERA, A. J.; GARRETT, J. M. Understanding interobserver agreement: the kappa statistic. Family Medicine Journal, v. 37, n. 5, p. 360-363, 2005.
VIEIRA, T. S.; VIEIRA, R. F.; FINGER, M. A.; NASCIMENTO, D. A.; SICUPIRA, P. M.; DUTRA, L. H.; DECONTO, I.; BARROS-FILHO, I. R.; DORNBUSCH, P. T.; BIONDO, A. W.; VIDOTTO, O. Seroepidemiological survey of Theileria equi and Babesia caballi in horses from a rural and from urban areas of Paraná State, southern Brazil. Ticks And TickBorne Diseases, v. 4, n. 6, p. 537-41, 2013.

VIEIRA, T. S. W. J.; VIDOTTO, O.; GUIMARÃES, A. M. S.; SANTOS, A. P.; NASCIMENTO, N. C.; FINGER, M. A. P.; BARROS-FILHO, I. R.; DORNBUSCH, P. T.; BIONDO, A. W.; VIEIRA, R. F. C.; MESSICK, J. B. Use of pan-hemoplasma PCR for screening horses highly exposed to tick bites from southern Brazil. Semina: Ciências Agrárias, Londrina, v. 36, n. 1, p. 291-294, 2015.

WORLD ORGANISATION FOR ANIMAL HEALTH - OIE. Equine piroplasmosis: manual of diagnostic tests and vaccines for terrestrial animals 2.5.8. [S.1. : s.n.], 2014. Available at: <http://www.oie.int/internationalstandard-setting/terrestrial-manual/access-online/>. Accessed at: 20 sept. 2015. 